\title{
A PRESENÇA KAINGANG NO MORRO DO OSSO ENTRE DIFERENTES PERSPECTIVAS SÓCIO-DISCURSIVAS
}

\author{
LUIZ GUSTAVO SOUZA PRADELLA ${ }^{1}$ \\ UFRGS
}

JOSÉ RODRIGO SALDANHA ${ }^{2}$

UFRGS

\begin{abstract}
RESUMO: Este artigo tem como tema central diferentes elementos sócio-discursivos acionados por atores distintos diante do estabelecimento da aldeia Kaingang (Tupeng-pó) no Morro do Osso, perímetro urbano da cidade de Porto Alegre. Buscamos assim, analisar a dimensão da tensão relacional instaurada entre atores não-indígenas habitantes da urbe ambientalistas, ecologistas, politicos e representantes de associações de moradores - e o grupo Kaingang da aldeia Tupeng-pó. Resgatando o conceito de ambiência de Baudrillard nos termos de uma orientação cosmológica que busca definir formas e dinâmicas espaciais, pretendemos analisar como os espaços da cidade e da mata são percebidos por cada um dos atores envolvidos, ou seja, de que maneira estas ambiências se relacionam num contexto de conflito.
\end{abstract}

PALAVRAS-CHAVE: etnografia; kaingang; Porto Alegre; Morro do Osso; ecologia.

ABSTRACT: This paper has focus different social-discursive elements driven by different actors resulted by the establishment of Kaingang community (Tupeng-pó) in the Morro do Osso, located in Porto Alegre's urban perimeter, a south brazilian capital. Therefore we persuit to analyze the relational tension between the different actors: non-indigenous urban inhabitants (environmentalists, ecologists, politicians and neibourhood assembly chairmen) and the Kaingang community Tupeng-pó. Retrieving the ambience concept of Baudrillard in the terms of a cosmological orientation that defines patterns and spatial dynamics we intent to analyze the perception of spaces like the city and the wood by the involved actors, therefore, in a conflictive context the ways that these ambiences are relating to each other.

KEYWORDS: etnography; kaingang; Porto Alegre; Morro do Osso; ecology.

\footnotetext{
1 Mestrando do Programa de Pós-Graduação de Antropologia Social - PPGAS/IFCH/UFRGS. Pesquisador associado ao Núcleo de Antropologia das Sociedades Indígenas e Tradicionais NIT/IFCH/UFRGS e ao Laboratório de Arqueologia e Etnologia LAE/IFCH/UFRGS. E-mail: gustavopradell@gmail.com .

2 Mestrando do Programa de Pós-Graduação de Antropologia Social - PPGAS/IFCH/UFRGS. Pesquisador associado ao Núcleo de Antropologia das Sociedades Indígenas e Tradicionais NIT/IFCH/UFRGS e ao Laboratório de Arqueologia e Etnologia LAE/IFCH/UFRGS. E-mail: irsalbr@yahoo.com.br.
}

Espaço Ameríndio, Porto Alegre, v. 2, n. 2, p. 52-82, jul./dez. 2008. 
SALDANHA e SOUZA PRADELLA - A presença Kaingang no Morro do Osso ...

Cada vez mais me parece que a formação dos discursos e a genealogia do saber devem ser analisadas a partir não dos tipos de consciência, das modalidades de percepção ou das formas de ideologia, mas das táticas e estratégias de poder. Táticas e estratégias que se desdobram através das implantações, das distribuições, dos recortes, dos controles de territórios, das organizações de domínios que poderiam constituir uma espécie de geopolítica... (FOUCAULT, 1998, p.165).

Será possível reconstituir no panorama anterior ao período colonial a distribuição "original" dos ancestrais dos grupos indígenas atuais para além das suposições, neste continente que, como resultado de jogos de poder, foi historicamente denominado "América"? Quais são os desdobramentos em termos de corpo, espaço e discurso relacionados a diferentes perspectivas?

Através da etnografia de diferentes pontos discursivos buscamos analisar os imbricamentos das questões acima colocadas no que se refere às possibilidades reflexivas por estas apresentadas. Os fatos sociais analisados tratam do estabelecimento da Aldeia Kaingang Tupeng Pó (Pé de Deus), no popular-localmente conhecido "Morro do Osso".

Em termos metodológicos este trabalho também tem por finalidade realizar-se sobre as múltiplas relações vinculadas, bem como nos elementos sócio-discursivos acionados pelos diferentes atores biólogos, acadêmicos, agentes da FUNAI, moradores locais, funcionários da prefeitura, estagiários - que, além dos Kaingang, manifestaram-se de alguma forma em reação à presença destes últimos no Morro do Osso. Buscando desenvolver uma leitura qualificada sobre as relações estabelecidas entre as perspectivas neocolonialista ${ }^{3}$ e indígena,

\footnotetext{
${ }^{3}$ O termo "neocolonialismo" se distingue do conceito de "colonialismo" pelo tipo de dominação exercida. Não se trata mais da influência ou dominação violenta a que temos referências do passado exercida por um país sobre uma nação ou minoria em seus espaços, geralmente através de empresas coloniais ou operações militares; faz referência a tipos específicos de violência, não mais entre "sociedades", mas fluido em formas distintas de socialidade, relativamente mais sutil, ainda que efetivo, promovida por grupos sociais detentores de poderes econômicos e/ou políticos, privados ou estatais que exercem formas de dominação na defesa de seus interesses em detrimento das necessidades primárias de quaisquer outras populações que possam ser afetadas.
} 
SALDANHA e SOUZA PRADELLA - A presença Kaingang no Morro do Osso ...

objetivamos refletir nos termos de uma ambiência ${ }^{4}$ fundada na relação entre corpo/espaço/discurso.

Situado na Zona Sul de Porto Alegre próximo às margens do rio Guaíba, o Morro do Osso atinge uma altitude de 143 metros, estando a $30^{\circ} 07^{\prime} \mathrm{S}, 51^{\circ} 14^{\prime} \mathrm{W}$. Este é reconhecido historicamente por ser espaço, num tempo imemorial, de um cemitério indígena (MIRAPALHETE, 2001).

Atualmente a urbanização nesta região é crescente: a expansão de condomínios de moradores de "expressivo poder aquisitivo" se evidencia; suas construções avançam o terço superior do morro sobre a área que por decreto federal é protegida contra a urbanização ${ }^{5}$. Deve-se levar em conta também à existência de outras pressões sobre os espaços considerados "não-habitados" e ilhados por uma pretensa "urbanicidade". Tal configuração espacial é resultado direto dos jogos de poder que pautam e definem homogeneamente aquilo que se concebe como "cidade".

No ano de 1979, o morro ganhou status de área de preservação ecológica no plano diretor da cidade de Porto Alegre/RS. Além da área urbanizada do morro, existem aproximadamente 220 hectares de dita "área natural". Na década de 1980 e início da década de 1990, ecologistas e moradores da zona sul iniciaram manifestações a favor da instalação de um parque de proteção ambiental no Morro do Osso, criando a "Comissão Permanente de Defesa do Morro do Osso" (CPDMO) (MIRAPALHETE, 2001).

Em Junho de 1994 foi criado pela Prefeitura Municipal de Porto Alegre o "Parque Natural do Morro do Osso", com um total de 110 hectares, sendo que destes, a prefeitura possuía apenas a escritura de 27 hectares. Em 1998, a prefeitura construiu a sede administrativa do parque (MIRAPALHETE, 2001). No ano de 2000 a prefeitura negociou com o proprietário de uma área de 42 hectares pertencentes aos 110 hectares que, no plano diretor da cidade, eram referentes ao parque a quantia de quase 30 hectares destes. Nesta negociação foi acertado que o proprietário teria o direito de lotear os demais 12 hectares que estavam embargados por estarem contidos dentro da área estipulada

\footnotetext{
${ }^{4}$ Cf. Baudrillard (1993).

${ }^{5}$ Ver em anexo 2 (foto B).
} 
SALDANHA e SOUZA PRADELLA - A presença Kaingang no Morro do Osso ...

como de "proteção ambiental". Feito um acordo, a Prefeitura Municipal de Porto Alegre passou a ter a escritura de 57 hectares.

A partir de nossos trabalhos de campo junto a segmentos das Biociências, tomamos também conhecimento que no início do ano de 2004 iniciou-se o processo de loteamento habitacional sobre os 12 hectares que haviam sido concedidos na permuta entre o poder local e este proprietário específico. Segundo os "especialistas" em questão, este fato se configurava numa grande contradição, uma vez que se tratava de uma imprescindível parcela de mata densa e menos "degradada pela ação humana", um "corredor de passagem" e conexão entre parcelas maiores de mata, que seriam então esfaceladas. Nesta área verde ainda habitava um grupo de Bugios-Ruivos, (denominados taxinomicamente pela biologia Alouatta guariba clamitans). As concessões do Poder Municipal ao usufruto da supracitada área de 12 hectares na forma de loteamento, na opinião dos especialistas, colocavam em questão a validação do "Parque Natural do Morro do Osso" enquanto espaço propriamente dito de "preservação".

Retrospectivamente, no final do ano de 2003 - portanto, antes do estabelecimento dos Kaingang no Morro do Osso - o Núcleo de Antropologia das Sociedades Indígenas e Tradicionais (NIT) foi acionado pela direção do Parque Municipal do Morro do Osso devido a uma preocupação em tentar localizar o cemitério indígena ali referido. A partir deste contato formou-se um grupo, entre professores e estudantes, para averiguação da existência de um possível sítio arqueológico no espaço do morro, bem como um primeiro contato com funcionários do parque e moradores das imediações. Naquela ocasião, foi possível constatarmos que a direção e funcionários do parque sabiam da presença eventual de indígenas ali: fomos notificados pelos guardas-parque da presença relativamente constante de indígenas que por vezes foram avistados e afugentados dali por estarem em meio à mata "arrancando" os cipós e "destruindo" a vegetação. No contexto urbano a etnia kaingang se mantém em grande parte através da confecção e venda de artesanatos. Existem entre estes muitos habilidosos artesãos, conhecedores de diversas técnicas de cestaria que possuem como principal matéria prima fibras de cipó e taquara. Em Porto Alegre a matéria prima constitui-se basicamente de diversos tipos 
SALDANHA e SOUZA PRADELLA - A presença Kaingang no Morro do Osso ...

de cipós, sendo coletados no complexo de morros e áreas verdes da cidade através de técnicas tradicionais (FREITAS, 2006).

Alguns meses depois, na primeira semana de abril de 2004, um grupo Kaingang proveniente da Emã Fág Nhin (conhecida entre os brancos como "Aldeia da Lomba do Pinheiro") ${ }^{6}$, bem como de algumas vilas da cidade de Porto Alegre, estabeleceram um wäre às margens do caminho principal do parque ${ }^{8}$, próximo à sede deste, aos pés de uma Acácia Negra. Em sua maior parte, aqueles kaingang provenientes da "Aldeia Kaingang da Lomba do Pinheiro" eram membros de uma facção que há muito vinha rompendo com outras lideranças daquela aldeia e com os seus buscavam outros espaços onde pudessem viver segundo seus referenciais.

No dia dezessete do mesmo mês, os Kaingang estabelecidos no Morro do Osso foram surpreendidos por uma intervenção orquestrada pela Prefeitura de Porto Alegre, e conduzida por alguns funcionários municipais com o apoio de soldados da Brigada Militar Estadual que, deslocando um caminhão e duas viaturas para o local, tinham o intuito de removê-los dali. Nesta operação foram apreendidos diversos materiais que eram de posse dos Kaingang: cobertores, lonas, cordas, cipós, roupas, uma grande quantidade de alimentos perecíveis principalmente carne a ser preparada para a comemoração do dia 19 próximo, o "Dia do Índio" no "calendário nacional".

Diante da desocupação, alguns kaingang argumentavam com os operadores da Prefeitura em defesa de seu direito a permanecer no parque; outros, confusos perante a pressão, de baixo de uma chuva fina que caía na ocasião, subiram com seus materiais no caminhão, sendo, assim, levados através do morro para a outra extremidade deste, onde havia uma cancela definindo os "limites" do parque. Ali foram deixados sem seus materiais, logo após esta cancela, na localidade popularmente

\footnotetext{
${ }^{6}$ Área cedida para os Kaingang pela Prefeitura Municipal de Porto Alegre no bairro de mesmo nome. Atualmente habitam nesta 26 famílias, somando cerca de 120 pessoas.

${ }^{7} \mathrm{O}$ termo wäre é utilizado entre os Kaingang como denominação de espaços de ocupação recente e/ou temporária. Em algumas terras indígenas (TI), algumas "famílias" relacionam a constituição dos wäre à finalidades sazonais de caça, pesca ou cuidado de roças mais afastadas das áreas de suas moradias (TOMMASINO, 2002). No contexto de luta pela terra e reivindicações políticas, os wäre passam a desempenhar também um papel considerável em relação aos deslocamentos constantes, onde a permanência em faixas de beiras das estradas, por exemplo, também são caracterizadas enquanto tal.

${ }^{8}$ Ver anexo 3 (Foto C).
} 
SALDANHA e SOUZA PRADELLA - A presença Kaingang no Morro do Osso ...

conhecida como "Sétimo Céu"9. Pouco tempo depois, aqueles que haviam permanecido próximo à sede deslocaram-se também para o outro lado do morro, onde juntos constituíram um novo wäre ${ }^{10}$ com auxílio do Conselho Indigenista Missionário (CIMI) e de outras entidades e pessoas. Com o passar do tempo este wäre deu origem a um Emã, uma ocupação permanente.

Com a presença Kaingang no morro, os funcionários da prefeitura, incluindo seu corpo administrativo, mostravam-se confusos com relação aos procedimentos a serem tomados. Sob ordens da direção, guardas municipais, além dos eventuais guarda-parques, encontravam-se agora aquartelados na sede administrativa. Junto ao local onde estava o wäre, próximo a outra entrada do parque, um "posto policial" havia sido improvisado logo após a cancela, demarcando a fronteira entre o espaço do parque e aquele ocupado pelos Kaingang. Uma barraca verde-oliva de estilo militar fazia vez desse posto, onde mais guardas-parque e guardas municipais haviam sido deslocados e montavam guarda constante. Sobre este episódio, Rauber nos relata:

Os guardas municipais estavam acampados em uma barraca de modelo militar que fechava o caminho da estrada, junto ao portão do parque. Para chegarmos ao acampamento Kaingang tive que passar por dentro da barraca, caminhar alguns poucos metros e pular a cancela. [...] Os Kaingang montaram suas barracas nos dois lados da estrada que seguia do lado de fora do parque, nas laterais que possuíam sua extensão margeada por capoeirão. Capoeirão que morre onde se inicia o condomínio Sétimo Céu (RAUBER, 2005, p. 8).

No dia 28 de abril, funcionários da Fundação Nacional do Índio (FUNAI) entraram em contato com os administradores do Parque Natural do Morro do Osso na sede do próprio parque. Ali procuraram sua Diretora, Maria Carmem Sestren Bastos. Neste dia nos encontrávamos por lá e Maria Carmem nos relatava suas últimas ações na "defesa" do parque, mostrando o que havia sido "apreendido" com os Kaingang

\footnotetext{
${ }^{9}$ A apreensão dos materiais pelos funcionários da Prefeitura Municipal de Porto Alegre naquele dia chuvoso de abril teve um tal impacto no grupo que, desde então, motivaram uma série de manifestações artístico-culturais - músicas e narrativas - tratando deste episódio.

${ }^{10}$ Ver anexo 1 (Foto A).
} 
SALDANHA e SOUZA PRADELLA - A presença Kaingang no Morro do Osso ...

pelos guardas: alguns rolos de cipó, que seriam usados para fabricação de artesanato.

Posteriormente fomos informados pelos Kaingang no segundo wäre que a maior parte deste cipó havia sido coletada no Morro Santana, e que haviam trazido estes junto com seus outros materiais. Este morro, outro importante espaço dito "natural da cidade", localizado na área limítrofe entre os municípios de Porto Alegre e Viamão, é uma zona de matas, campos e cursos d'água, e assim, outro importante espaço de trânsito e ambiência kaingang "1 na região de Porto Alegre.

Ao contatar a diretora, os técnicos da FUNAl foram sucintos e diretos ao informar a esta a impossibilidade de ação da Prefeitura de Porto Alegre e da direção do Parque em relação aos Kaingang acampados no Morro do Osso. Uma vez que o procedimento padrão de tratar questões indígenas através da FUNAI havia sido desconsiderado pelos funcionários da prefeitura, os técnicos do órgão público federal para assuntos indígenas caracterizaram como irregulares todas as ações da prefeitura em relação aos Kaingang presentes no Morro do Osso. Dito isso, os técnicos requisitaram que os materiais dos indígenas apreendidos no dia 17 de abril fossem imediatamente devolvidos a estes.

Diante da requisição, Maria Carmem informou que nada poderia fazer e que os técnicos da FUNAl deveriam entrar em contato com sua superior. Através do telefone da própria sede do parque, os técnicos da FUNAI contataram Simone Rodrigues Mirapalhete, então Diretora da Divisão de Parques da Secretaria Municipal do Meio Ambiente de Porto Alegre (SMAM/PMPA). Esta informou o local onde se encontravam os materiais apreendidos: um dos armazéns do cais do porto da cidade. Sob o desfecho deste evento Rauber também relata:

Obtive informações junto aos kaingang e funcionários do parque de que quando a FUNAI juntamente com os kaingang abriram as portas do depósito (...) encontram carne putrefata misturada com roupas, cobertores e demais pertences (RAUBER, 2005, p. 9).

\footnotetext{
${ }^{11}$ Há mais de 10 anos, após negociações com a Universidade Federal do Rio Grande do Sul, gestora deste espaço, os Kaingang adquiriram autorização para livre circulação e eventual retirada de substâncias do Morro Santana - braços de cipó, ervas medicinais, mel, sementes, por exemplo - originadas nas matas deste morro e tidas como fundamentais na manutenção e atualização de sua vivência.
} 
SALDANHA e SOUZA PRADELLA - A presença Kaingang no Morro do Osso ...

Os dois argumentos principais que motivaram os indígenas em relação a seu estabelecimento no Morro do Osso baseavam-se em questões referentes ao passado e ao presente, expressos pelo sentimento de sacralidade desta paisagem e seus elementos no cotidiano e história indígena.

Os Kaingang reconheciam o cemitério existente no morro como de sua ancestralidade. Antes de se estabelecerem no morro, a própria Prefeitura de Porto Alegre em seu website na Internet divulgava a existência de um sítio arqueológico de um cemitério indígena no Morro do Osso no tópico sobre informações turísticas. Tais informações eram decorrentes do fato do próprio morro ter recebido seu nome devido a relatos de que era comum no século XVIII e XIX serem encontrados ossos indígenas naquela região, como registrado nas crônicas do escritor e jornalista José Antônio do Vale Caldre e Fião (CALDRE E FIÃO, 1943) do século XIX. Este autor considerava grande a possibilidade da existência de um cemitério indígena no local.

Diante destas constatações, no entendimento das lideranças religiosas (Kujã) havia a necessidade da realização de um Kikikóia ritual de encaminhamento dos mortos das duas metades cosmológicas e devolução dos respectivos nomes aos vivos ${ }^{12}$ :

Tido como a mais significativa referência de uma antiga presença ancestral indígena neste espaço, o local exato do cemitério jamais foi localizado. No entanto, sua inexistência material, pouco importa já que sua concretude e autenticidade encontram-se intrinsecamente relacionadas à pequenas reminiscências. As evidências necessárias para tal surgem na forma de uma pedra de percussão e de corte, e de uns poucos cacos de cerâmica encontrados pelos próprios Kaingang. (...) Nesse sentido que o cemitério emerge como uma das principais motivações da presença Kaingang no Morro do Osso. Este é

\footnotetext{
${ }^{12} \mathrm{O}$ que está fundamentalmente em jogo aqui não é a forma histórico-científica reconhecida como legitima pelo pensamento ocidental, mas sim elementos da mitologia Kaingang e sua forma de compreensão do cosmos concebida socialmente sem propriamente um interior. Para ilustrar essa idéia basta uma simples comparação da forma como Kaingang e Guarani compreendem a cidade. Enquanto os Guarani relacionam esta a um espaço perigoso no qual eventualmente com a devida proteção busca-se a obtenção de recursos, de forma muito relativamente semelhante a sua relação com o espaço da floresta, para os Kaingang a cidade é pensada nos termos de uma grande aldeia, na qual eles e os outros podem se inserir e relacionar-se de forma complementar. O que importa para os Kaingang não é a verdade dos brancos que inclui os índios, mas sim a sua própria verdade, as narrativas de seus velhos - estas incluem os guaranis, os brancos e os não-humanos - sobre sua presença e agência nos espaços ocupados.
}

Espaço Ameríndio, Porto Alegre, v. 2, n. 2, p. 52-82, jul./dez. 2008. 
SALDANHA e SOUZA PRADELLA - A presença Kaingang no Morro do Osso ...

constantemente tratado por eles em termos de 'seu valor de ancestralidade' (SOUZA PRADELLA, 2007, p. 10) [\#] um fantasma de um núcleo de realidade de que vive toda consciência mitológica e individual fantasma da projeção de um detalhe que vem a ser o equivalente do eu e através do qual se organiza o resto do mundo (BAUDRILLARD, 1993, p. 87).

A outra motivação, relacionada muito ao presente cotidiano kaingang em Porto Alegre tratava da emergência de salvamento da mata e de seus espaços referenciais. Como mencionado anteriormente, era de pleno conhecimento dos biólogos e estagiários, assim como da direção do parque, a eminente destruição de 12 hectares da mata, entendida por estes "cientistas" como um "corredor verde", para construção de um loteamento habitacional. Este fato também era de conhecimento dos Kaingang que em suas caminhadas pelo morro na busca por cipó, já haviam descoberto no interior da mata as placas de demarcação com números e letras das futuras quadras e ruas do loteamento. As palavras do atual vice-cacique do grupo são claras com relação à importância dada aos elementos constituintes da paisagem:

... essa pedra aqui pra nós, ela tem muito valor. Esse morro aqui é uma riqueza para nós. Riqueza de natureza, de mato, de paisagem, mas agora, se nós não chegasse, se nós não segurasse esse morro, esse morro ia acabar sendo uma cidade, ia terminar, daqui mais um tempo só ia se enxergar uma praça aqui em cima. Esse mato não ia mais existir. Onde é que nós falamos que tava sendo loteado é aqui embaixo nesse mato aqui [apontando para a mata na parte sul do morro]. Ali embaixo já tinha até nome de rua. Ali tem madeiras, madeiras nativas de anos, que ia ser terminado, ia ser derrubado (...) ia ser construído os condomínios (...) mas nós chegamos aqui, seguramos o mato, porque nós índios não queremos que o mato termine (Francisco Rókãn apud FAGUNDES e SOUZA PRADELLA, 2006).

Ainda no ano de 2004, outras ações dos fög (brancos/não-índios) marcariam e apresentariam-se como alternativas de "intervenção" a presença dos Kaingang no Morro do Osso: "denuncias" de descaso e maus tratos com as crianças pelos indígenas, perpetradas por moradores da localidade Sétimo Céu contra os Kaingang; campanhas 
SALDANHA e SOUZA PRADELLA - A presença Kaingang no Morro do Osso ...

difamatórias erigidas na mídia local contra o grupo por "ambientalistas" e pela Prefeitura Municipal de Porto Alegre; não-reconhecimento da presença Kaingang no Morro do Osso por parte do governo federal, através da FUNAI, que se recusou terminantemente a reconhecer aos índios até mesmo o direito a um laudo antropológico que avaliasse sua presença na cidade.

Em 2005, no dia 04 de Junho, foi organizada uma caminhada pela "Associação de Bairro do Jardim Isabel" (ASCONJIP), no Morro do Osso. Segundo Rauber (2005), durante esta caminhada, ao chegarem ao platô do morro, a diretora do parque, Maria Carmen, observou que mais uma casa estava sendo erguida pelos Kaingang. Ao "passar um rádio para a sede", Maria Carmen pediu a um guarda-parque que notificasse o secretário municipal do Meio Ambiente, na ocasião "Beto" Moesch"13, do ocorrido. Segundo a própria diretora, em uma reunião ${ }^{14}$, a reação do secretário ao telefone nesse dia foi a seguinte: "Tira essa casa agora!" Posteriormente, a diretora relatou ainda que se recusou a atender à demanda do secretário. Este, irritadiço, respondeu: "Então eu vou aí". A diretora e os demais participantes da caminhada ficaram então esperando o secretário numa das entradas do parque, junto à sede, quando receberam a notícia que o secretário havia sido "agredido" pelos Kaingang. Ao invés de buscar encontrar os participantes da caminhada, o secretário teria chegado diretamente ao espaço do segundo wäre. Sobre o evento ocorrido entre os Kaingang no Morro do Osso e Moesch, as lideranças Kaingang redigiram uma nota pública que, no dia 06 de junho, passou a ser veiculada por meios de mídia alternativos ${ }^{15}$.

Deve-se destacar aqui as inúmeras estratégias desenvolvidas pelos kaingang em contraponto às reações negativas despertadas nos setores supracitados. Os indígenas buscaram intensificar as alianças com instituições e segmentos sociais diversos: "acadêmicos" e outros universitários, missionários religiosos, advogados, ONG's consideradas

\footnotetext{
${ }^{13}$ Este mesmo secretário, na ocasião da entrada dos Kaingang no Morro do Osso, chegou a afirmar nos veículos de mídia local que "os índios" haviam invadido o parque incitados por antropólogos da Universidade Federal do Rio Grande do Sul, ignorando o longo histórico de protagonismo kaingang na luta pela terra no sul do Brasil.

${ }^{14} \mathrm{O}$ relato sobre o breve diálogo com o Secretário do Meio Ambiente foi transmitido durante uma reunião com ambientalistas, biólogos, veterinários, representantes de ONG's, funcionários do parque e de outros setores da Prefeitura Municipal de Porto Alegre, no dia 15 de junho, denominada "Relato dos últimos acontecimentos em relação ao grupo acampado no Morro do Osso" na sede do parque.

${ }^{15}$ Ver anexo 04.
}

Espaço Ameríndio, Porto Alegre, v. 2, n. 2, p. 52-82, jul./dez. 2008. 
SALDANHA e SOUZA PRADELLA - A presença Kaingang no Morro do Osso ...

"aliadas" por estes, além de órgãos governamentais não alinhados a FUNAI e aos setores da Prefeitura Municipal de Porto Alegre que voltaram-se contra a presença kaingang no morro. Além destas "alianças", em diversas ocasiões, palestraram em escolas e universidades, e também se apresentando em eventos e feiras. Podemos destacar, por exemplo, sua participação no "V Fórum Social Mundial" em Porto Alegre, onde apresentaram seu grupo de dança e canto ${ }^{16}$. Também na Aldeia do Morro do Osso passaram a receber estudantes universitários, pessoas simpatizantes com as "causas dos povos indígenas" ou mesmo curiosos. Nessas ocasiões muitas vezes organizavam visitas as matas do Morro do Osso e apresentavam suas habilidades com a cestaria e artesanato em geral.

A partir dos elementos etnográficos descritos, mesmo que de maneira breve não temos como intenção analisar somente os eventos sociais referentes às particularidades da presença Kaingang no Morro do Osso, mas também alguns dos posicionamentos de diferentes atores sociais ${ }^{17}$ que se manifestaram diante desta presença. Enquadramos aqui estes posicionamentos naquilo que identificamos como perspectiva neocolonialista. Esta opção é proposital, uma vez que parece-nos que qualquer análise de grupos indígenas em situação de contato intenso que não leve em conta o contexto neocolonial vivenciado por estas populações acaba por ocultar elementos de importância central para a compreensão da dinâmica atual ou mesmo do passado destas sociedades $^{18}$.

É nesse sentido que buscamos fundamentalmente compreender as diferentes perspectivas pelas quais são construídas a identidade e a alteridade, e de que forma influenciam na definição de diferentes concepções de paisagem, espacialidade, territorialidade, ambiência, corporalidade e agência: não somente de "si", ou do próprio "estar" (MERLEAU-PONTY, 1994), mas também enquanto projeto para o "outro".

\footnotetext{
${ }^{16}$ Este evento foi documentado pelo NIT/UFRGS e deu origem ao vídeo Dualismo Kaingang em Perspectiva: Dinâmica da Construção da Imagem 15 min. NTSC Cor Brasil, 2005, sobre a participação dos Kaingang no Fórum Social Mundial de 2005.

${ }^{17}$ Evidentemente não poderemos abordar todos os atores relacionados a presença dos Kaingang no Morro do Osso já que seriam necessárias muito mais páginas do que compete a este tipo de texto. Logo através de um recorte buscamos apresentar os principais grupos sociais em situação de tensão neste contexto.

${ }^{18}$ Tal ocultamento incorre em implicações éticas e políticas, decorrendo num posicionamento por parte do cientista, e mesmo que velado é ao mesmo tempo político e epistemológico.
} 
SALDANHA e SOUZA PRADELLA - A presença Kaingang no Morro do Osso ...

Empregamos aqui o conceito 'ambiência' enquanto um conjunto de referenciais historicamente constituídos que criam e recriam simbolicamente - a partir de uma bagagem simbólica, um ambiente considerado "familiar" a partir de sua naturalização:

O sistema de ambiência é extensivo, mas caso se pretenda total, é preciso que recupere toda a existência, conseqüentemente também a dimensão fundamental do tempo. Não se trata, é claro, do tempo real, são os signos ou indícios culturais do tempo, que são retomados (...) natureza e tempo, nada the escapa, tudo se efetua nos signos (BAUDRILLARD 1993, p. 82).

$\mathrm{Na}$ concepção de Baudrillard, a ambiência não é somente a ocupação de um espaço, mas sim sua constituição enquanto referencial processual sobre o espaço e seus elementos percebidos, manejados e descritos, invariavelmente através de parâmetros sociais.

Para fins analíticos consideramos dois os objetos etnográficos centrais a serem trabalhados: os elementos da ordem do discurso e ações previamente apresentadas; e as conexões conjunturais e eventuais entre os diferentes atores envolvidos. Busca-se com isso a explicitação do campo de correlações de forças estabelecidas em torno da problemática da presença indígena nos espaços da cidade, tomando como exemplo a presença Kaingang no Morro do Osso. É nesse sentido que elegemos as colocações dos participantes de uma das reuniões do "Conselho Consultivo do Parque Natural do Morro do Osso". A reunião em questão, ocorrida em Junho de 2005 - já mencionada anteriormente - foi etnografada por Rauber (2005) e tinha como pauta principal tratar "dos últimos acontecimentos em relação ao grupo acampado no Morro do Osso" 19.

Um dos aspectos constantes em relação aos discursos proferidos nas esferas de poder do empreendimento neocolonial a respeito dos grupos indígenas se caracteriza pela negação velada das diferentes formas de "ser" e "estar" dos indígenas. No período colonial era colocada

\footnotetext{
${ }^{19}$ Rauber (2005, p. 14) apresenta-nos a lista de presença da reunião: A diretora do parque; um integrante do grupo de escoteiros Nimuendajú; uma funcionária da SMED; uma funcionária do Escritório de Turismo de Porto Alegre; um funcionário do Instituto Ligia Pratini de Moraes; uma representante da organização não-governamental Mirasserra e uma veterinária de animais silvestres.
} 
SALDANHA e SOUZA PRADELLA - A presença Kaingang no Morro do Osso ...

em dúvida a completude dos ameríndios enquanto seres humanos ${ }^{20}$. Hoje a estas populações estão vetadas, por decreto e desconhecimento, algumas de suas mais caras concepções.

\begin{abstract}
Devemos tratar desse assunto de uma forma desinteressada, sem cair no simplismo de apenas acusar o caráter etnocidário da civilização que se criou "brasileira". Deve-se fazer a análise naquilo que subjaz como herança do passado a condicionar os atos e pensamentos presentes, numa leitura que faça compressão dos acontecimentos contemporâneos envolvendo descendentes de europeus e de nativos, mestiçados e hierarquizados numa única e mesma estrutura desigual (SOUZA, 2004, p. 186).
\end{abstract}

Para muitos brasileiros é pela ausência que se define o indígena. Sem fé, sem lei e sem rei ${ }^{21}$ : aquilo que no século XVI se dizia dos índios, com pouquíssimas transformações é ainda um discurso amplamente vigente também nas instituições eurocentradas dos nossos dias. A partir dessa perspectiva tudo aquilo que não possa ser identificado através da comparação às formas euroreferenciadas - conceber a política, organizar o espaço e pensar o corpo - não existe. Nesse sentido o "índio" é como uma criança, alguém "a ser ensinado". Suas formas particulares de política, espacialidade, corporalidade e religiosidade são ignoradas, deixadas de lado em nome do "certo", dos padrões que o indígena "evoluído" e "instruído" deve assimilar:

Eles têm que aprender junto com o homem branco a evoluir. Eles não querem que essas crianças vão à escola. Aquelas crianças caminham de pés descalços nos paralelepípedos, é sobre-humano. Buscam baldes pesados de água. Considero isso trabalho infantil (Funcionário do Parque Municipal do Morro do Osso apud RAUBER, 2005, p. 16).

Este não é o único modo pelo qual os povos ameríndios em situação de contato são tratados pelo discurso neocolonialista. Outra

\footnotetext{
${ }^{20}$ Basta lembrarmos dos extensos debates teológicos que buscavam definir (decifrar) se os índios tinham ou não uma alma para ser salva.

${ }^{21}$ Convencionou-se caracterizar todos os índios do Brasil a partir do contato com os Tupinambá do litoral, como povos sem "fé, lei, ou rei", supostamente porque a língua tupinambá (tronco Tupi-Guarani), ou nheengatu, ou ainda língua geral, não tinha os referidos sons $f, l, r$. Uma tirada lingüística atribuída aos primeiros Jesuítas lingüistas a chegarem à costa brasileira, durante a década de 1550 .
}

Espaço Ameríndio, Porto Alegre, v. 2, n. 2, p. 52-82, jul./dez. 2008. 
forma contemporânea de se referir aos indígenas consiste em um exame constante de sua "indigenicidade". Seus difusores se colocam numa posição de examinadores cuja meta geralmente é avaliar o grau de "pureza", de "degradação" ou "perda" da "cultura indígena". Esta avaliação se dá, não pelos padrões e valores dos grupos étnicos em questão, mas a partir de uma comparação com o padrão de "índio puro", pleno de "exoticidade" em relação aos padrões ocidentais, "harmonioso" na sua relação com o "ambiente natural", "ingênuo" e "primitivo" no que se refere aos saberes técnicos e políticos, exigido insistentemente pela imaginação dos ocidentais ${ }^{22}$.

Qual é a origem da tribo? Eu tenho origem indígena, me criei no Morro do Osso, quero saber se são uma tribo indígena [...] a vida tem prioridade, tem coisa em extinção aqui, os índios não vivem em harmonia com a natureza. [...] Eu acho ingenuidade achar que esses que dizem que são índios não têm uma artimanha política que os move (representante da ONG Mirasserra apud RAUBER, 2005, p. 17).

Temos que ver que existem vários níveis dentro da ecologia existe a ecologia humana. Existe uma degradação na ecologia do índio que bebe... Não podemos ficar só na questão do sistema natural degradado (Funcionária da SMED apud RAUBER, 2005, p. 16).

Souza (2004) nos apresenta uma possível leitura deste fenômeno, e sua possível origem bíblica dentro da matriz do pensamento ocidental:

Desde então, o conceito "índio" tem servido
historicamente para traduzir percepções distorcidas,
geralmente românticas sobre um suposto "bom
selvagem" americano, como se nossos aborígenes
fossem cópias fiéis daquilo que Adão e Eva foram no
paraíso judaico-cristão antes do pecado original
(SOUZA, 2004, p. 190).

Através de sua obra, Oliveira Filho (1999) traz à reflexão à importância do estudo da conjuntura histórica e das dinâmicas culturais dos povos indígenas. Dimensões estas que por muito tempo foram

\footnotetext{
${ }^{22}$ Oliveira Filho discorre sobre este índio imaginário em sua obra (1999, p. 144).
} 
SALDANHA e SOUZA PRADELLA - A presença Kaingang no Morro do Osso ...

desconsideradas por algumas correntes do pensamento antropológico, estando este fato refletido indelevelmente no chamado "senso comum".

Muito tempo se passou e os brasileiros na virada do milênio não sentem qualquer obrigação ou sedução em identificar-se com os navegantes portugueses; mas não existe matéria jornalística, filme ou comercial de TV que não suponha que os índios sejam (ou devessem ser) os mesmos que foram descritos pelos cronistas. [...] O trauma provocado no europeu (ibérico) pelo encontro de uma forma tão radicalmente distinta de humanidade se consolidou na construção de uma categoria estética - o "índio" - evidente e autoexplicativa, inteiramente infensa à história: expressão completa da simplicidade, do passado e da primitividade. É essa categoria "plena, redonda e lisa", saturada de culpas e seduções, que o senso comum repete e consagra incessantemente (OLIVEIRA FILHO, 1999).

Enquanto uma das formas mais populares de pré-concepção em torno da imagem dos povos ameríndios, este pseudo-entendimento pode ser considerado elemento fundante de uma série de recursos disponibilizados por instituições do "Estado de Direito" na expectativa de essencializar os elementos diacríticos das unidades sociais e definir com maior grau de "certeza" a "distinção" dos índios em relação aos não-índios:

Mas nada se passa conforme tal expectativa. As formas culturais não revelam a mesma homogeneidade e regularidade que a transmissão genética, e as unidades sociais não são tão claramente recortadas, descontínuas e permanentes como os gêneros e espécies naturais. Sobretudo as unidades sociais mudam com uma velocidade e com uma radicalidade sem precedentes no âmbito do processo de evolução natural. As unidades sociais abandonam velhas formas culturais, recebem (e reelaboram) algumas de outras sociedades e ainda criam formas novas e distintas (OLIVEIRA FILHO, 1999, p. 169).

As implicações dos discursos neocoloniais possuem amplas conseqüências na legislação e nas relações estabelecidas com os povos indígenas pelas instituições da sociedade envolvente. Em termos de espacialidade, territorialidade e ambiência há uma clara imposição dos 
SALDANHA e SOUZA PRADELLA - A presença Kaingang no Morro do Osso ...

padrões da sociedade nacional eurocentrada em detrimento das formas ameríndias: é, por exemplo, erigida uma noção de "território tradicional" à imagem e semelhança de um "território nacional" com fronteiras, centros, periferias, etc. Entretanto as populações indígenas não são soberanas, mas sim tuteladas, "protegidas" pelo poder federal através do confinamento nestes espaços "oficiais" que tem como fim garantir a manutenção de sua "indigenicidade".

$O$ que 0 pensamento neocolonial desconhece (ou convenientemente faz questão de ignorar) são as conseqüências do confinamento sobre os grupos que supostamente estão sendo contemplados: no sul do Brasil são notórios os casos em que lideranças indígenas são empoderadas e aliciadas por poderes externos: pastores neopetencostais, "grileiros"23, fazendeiros e políticos locais. Tais alianças implicam em uma deterioração das relações intergrupais, alimentando diferenças entre facções (como no caso dos kaingang no Sul do Brasil, por exemplo) que devido ao confinamento acabam tendo que conviver lado a lado, por vezes a contragosto, ora compartilhando ora competindo por recursos que, em diversos contextos ainda são usurpados por eurodescendentes invasores das terras indígenas.

... o Estado brasileiro nega aos povos indígenas a propriedade de seu território, já que não existe no país a figura jurídica da propriedade comunitária. Embora a posse seja dos índios, a propriedade é da União. Na lei, o usufruto exclusivo dos índios aos recursos naturais de suas terras está perfeitamente assegurado. $\mathrm{Na}$ prática, os territórios indígenas são tomados como bens públicos e notoriamente objeto de invasões, usurpações e outros tipos de abuso (RITA RAMOS, 1991, p. 05).

O que se vê é a negação das formas geopolíticas descentralizadas dos autóctones, da territorialidade fluída, já que estas configuram um contraponto expressivo às noções de "propriedade 24 ", "estado-nação" e "política institucional", contrariando o cerne da organização políticoespacial dos modelos eurocentrados.

\footnotetext{
${ }^{23}$ Pessoas ou grupos sociais que usurpam através da violência os espaços de vivência e habitação de outras pessoas e ou grupos sociais.

${ }^{24}$ Seja esta propriedade estatal (pública) ou privada.
} 
SALDANHA e SOUZA PRADELLA - A presença Kaingang no Morro do Osso ...

Nesse sentido a presença de grupos indígenas nas cidades, como o caso dos Kaingang, Guarani e Charrua ${ }^{25}$ em Porto Alegre, não pode ser vista como um fato não-histórico, da contemporaneidade, uma inovação eventual em contraposição a sua tradição, mas sim o resultado processual da situação conjuntural de relações de tensão estabelecidas a partir do contato e do confinamento vivenciado. Esta presença definese como válvula de escape, fruto da adaptabilidade de sua sóciodinâmica, em conformidade com sua ambiência no espaço das cidades (bem como de seus arredores) que a eles também, como no caso dos não-índios, secularmente se impõe.

Como contraponto ao discurso neocolonial, o discurso Kaingang em questão evoca seu protagonismo nos embates pela terra, pela permanência dos elementos da mata no âmbito da cidade, na defesa dos parentes (vivos e mortos) e pela soberania das unidades familiares estas são suas principais motivações para a entrada no Morro do Osso.

O protagonismo kaingang em relação ao Morro do Osso surge em suas formas discursivas não somente em termos políticos, mas também relacionado a aspectos cosmológicos de suas formas sociais e religiosas particulares. Os Kaingang entram no morro para "segurar o mato" na iminência de sua destruição. $O$ mato é por excelência o espaço das plantas e dos animais, assim como dos cursos d'água e das formações rochosas, e todos estes elementos são entidades antropoformizadas, podem ser identificadas, são vistas como membros de "comunidades", sustentam relações de parentesco, são definidas enquanto pertencentes às metades - kamé ou kajrú - nas quais o cosmos encontra-se dividido (CRÉPEAU, 2002, p. 117). No sistema Kujã, os xamãs kaingang estabelecem relações estreitas com espíritos guias jagrẽ (ROSA, 2005, p. 4) entidades animais ou vegetais provenientes do domínio da floresta (SILVA, 2001, p. 119). Todos os nomes se relacionam diretamente a estes elementos, de forma que homens, mulheres, animais, plantas e rochas podem ser considerados "irmãos de metade", de substância (SILVA, 2001, p. 117) e origens comuns. Todos são "habitantes da mata", cada um dentro da sua respectiva metade complementa e é complementado pelos da metade oposta: assim seguem se contrapondo na mesma medida em que se completam.

\footnotetext{
${ }^{25}$ Outras etnias indígenas que hoje habitam a cidade de Porto Alegre.
} 
SALDANHA e SOUZA PRADELLA - A presença Kaingang no Morro do Osso ...

Se eu vejo a madeira morrendo eu fico triste... Aqui nós queremos mostrar pra nossos filhos que essas madeiras grossas, a gente abraça a madeira assim ó [abraçando um grosso tronco de uma árvore] porque ela é minha irmã, ela é meu irmão, essa madeira. Porque ele é do mato e eu também sou do mato por isso eu não gosto que destrói essas madeiras. Eu também sou do mato, e ela se criou no mato, e eu também me criei no mato, e eu não quero derruba essas madeiras... mas se eu deixar, quando é amanhã ou depois vão derrubar essa madeira bonita aqui, e eu não vou poder mais abraçar o meu irmão madeira (Francisco Rókãn ${ }^{26}$ apud FAGUNDES e SOUZA PRADELLA, 2006).

Em suas locuções os Kaingang apresentam sua concepção sobre o cipó (mrür) enquanto um sistema. Tal sistema foi detalhadamente trabalhado por Freitas (FREITAS, 2006) junto a diversos grupos Kaingang, habitantes na grande Porto Alegre. Para estes, as manchas de cipó, contendo diferentes variedades são - a imagem e semelhança das formas relacionais kaingang - também "comunidades".

As manchas são entendidas como o território de uma matriz ( $k a$ nèr), tronco que expande seus ramos (fèj) pelo solo da floresta em busca de um apoio para trepar (tãpry). (...) Zílio Jagtyg Salvador associa a matriz ao pai (panh) de uma família, sendo os ramos compreendidos como seus filhos (kòsin): "uma mancha de cipó é assim como uma família; o tronco-velho deles é o mais velho, é como o pai deles todos. Os mais novinhos é que correm em volta do pai e vão fazendo a vida deles." Quando perguntei a Zílio o que seria a comunidade, me respondeu: "a comunidade são os tipos todos que existem numa mancha, todos os pais de família, eles é que formam a comunidade, a aldeia deles; o gòjé (mancha) é a aldeia deles" (FREITAS, 2006, p.129).

Ressaltamos mais uma vez a centralidade do manejo do cipó e sua importância entre os grupos kaingang localizados nas cidades do sul do país. O artesanato feito com fibras vegetais é comercializado nas feiras

\footnotetext{
${ }^{26}$ Seu nome kaingang tem como significado 'madeira de proteção' - denominação das paliçadas feitas com madeiras resistentes que protegiam e cercavam as aldeias kaingang antes de sua "pacificação". Existe uma relação entre certos tipos de madeiras consideradas de sua própria metade cosmológica, neste caso, estes elementos - a árvore, a paliçada, e o nome de Francisco - são da metade Kamé.
}

Espaço Ameríndio, Porto Alegre, v. 2, n. 2, p. 52-82, jul./dez. 2008. 
SALDANHA e SOUZA PRADELLA - A presença Kaingang no Morro do Osso ...

e praças da grande Porto Alegre, sendo este largamente conhecido entre os porto-alegrenses. Como aponta Freitas, existe uma ampla gama de saberes cosmológicos, técnicos e estéticos relacionados ao cipó e sua presença no cotidiano kaingang. Por sua vez, devido ao próprio relevo da cidade, a maior parte das áreas verdes que restam em Porto Alegre encontram-se nos morros da cidade. É nestes que os kaingang exercem grande parte de suas atividades de manejo e coleta e reatualizam suas relações com o espaço da mata.

A ameaça a uma parcela do "sistema do cipó kaingang" (FREITAS, 2006) na forma de loteamento habitacional em uma das paisagens de ambiência e manejo, somada a necessidade de desvinculação faccional com a "Aldeia da Lomba do Pinheiro", fez com que diversas famílias se mobilizassem em torno da mudança para o Morro do Osso, espaço referencial para os kaingang. Deve-se ressaltar aqui que esta especificidade política que levou uma facção kaingang a buscar outros territórios devido a uma conjuntura de conflitos é a mesma que, intensificada pelas pressões decorrentes do confinamento, levou famílias extensas desta mesma etnia a se dispersarem em vilas na periferia de Porto Alegre, Viamão, e demais cidades da região metropolitana de Porto Alegre na atualidade.

Nestes elementos repousam os aspectos da reflexão acerca das noções de uma ambiência e uma paisagem kaingang, ambas como podemos observar atentamente pelos fragmentos de uma historicidade étnica kaingang fluída e dinâmica através dos séculos de colonialismo europeu no Brasil. Um povo que, como a esmagadora maioria dos povos indígenas, vem realizando deslocamentos, século após século, após contato, numa incessante fuga das pressões do expansionismo territorial dos empreendimentos neocoloniais. Uma busca por espaços entre aqueles ainda disponíveis - para exercerem livremente seus cotidianos particulares de vida, suas práticas e técnicas corporais específicas, aperfeiçoadas, refletidas, em interação e relacionalidade com todos os elementos do cosmos. Os kaingang vem há séculos sendo deslocados e deslocando-se de muitas das suas paisagens cotidianas, em busca de outras paisagens e de seus outros, englobando a ambos, paisagem e outros através de sua cosmovisão, em sua "sociedade". Através deste percurso, os kaingang vêm através do tempo 
SALDANHA e SOUZA PRADELLA - A presença Kaingang no Morro do Osso ...

desenvolvendo técnicas a partir de conhecimentos pré-existentes que acarretam uma interação e integração sistêmica aos complexos de paisagens verdes da região de Porto Alegre e seus elementos, como as "comunidades de cipós", e os "irmãos árvores".

É interessante notar essas especificidades da sócio-dinâmica kaingang em Porto Alegre quando nos detemos à presença Kaingang no Morro do Osso. Mais que requisitarem um espaço físico para habitarem, sua proposital resistência em meio à "urbanicidade civilizatória" nos coloca a par de uma complexidade cosmológica e simbólica que muitas vezes o modo de viver contemporâneo civilizado "desenvolvimentista" não consegue conceber, a não ser nos termos de uma utópica visão purista e utilitarista do "ambiente". Portanto, buscamos aqui evidenciar alguns dos elementos do ponto de vista kaingang acerca do espaço, onde a constituição da paisagem é povoada pelos "outros" que habitam seu cosmos. Tal noção de ambiência se distingue em muito daquela sustentada pelo dito "civilizado" que, por exemplo, elege a importância aos aspectos ditos "naturais" da paisagem por mero utilitarismo ou mesmo esteticismo, quando não enquanto apenas medida ecopolítica paliativa.

Ao desenvolver uma percepção qualificada sobre as relações estabelecidas entre as perspectivas neocolonialista e kaingang, vimos que ambas sustentam ambiências distintas, e de essências que conflitam. A perspectiva neocolonialista pretende-se hegemônica e única lógica aceitável, e sob esta perspectiva a territorialidade, assim como a corporalidade, pode ser domesticada, segmentada, sedentarizada a ponto de conformar as paisagens a uma essencialidade estática. Esta se reflete na criação e manipulação de espaços fixos, com limites claramente definidos, para além dos próprios processos históricos factuais e para além de outras concepções das paisagens.

É nesta perspectiva que podemos refletir acerca das estratégias geopolíticas acionadas por segmentos da Prefeitura Municipal de Porto Alegre em relação a sua "política ambiental", e trazidas à tona pela presença Kaingang no Morro do Osso. Enquanto falamos de "ilhas verdes", rodeadas pela urbe, estas não podem mais estar relacionadas às noções de "espaço selvagem" dos "civilizados", já que sua incorporação ao espaço "cidade" precisa ser total, quase que modelar. 
SALDANHA e SOUZA PRADELLA - A presença Kaingang no Morro do Osso ...

Tal modelo de "natureza" anacrônica estava sendo erigido no Morro do Osso antes do estabelecimento dos Kaingang. O conflito, resultado da tensão relacional tornou-se iminente, uma vez que um cemitério indígena, quase que uma "lenda urbana", passou a ser o marco de uma lembrança que, na concepção dos interessados na criação do parque, não deveria jamais estar relacionada aos indígenas atuais ${ }^{27}$. No entanto, quando os Kaingang assumiram o cemitério como pertencente a sua ancestralidade, este se mostrou enquanto mais um elemento de ambiência, a partir do qual uma ponte com um passado ${ }^{28}$ foi reforçada, gerando significados acionados em conformidade com o contexto de sua sócio-dinâmica presente.

Sob esse prisma resgatamos nossos questionamentos iniciais - as suposições a respeito da distribuição original dos ancestrais dos atuais grupos indígenas e o feixe corpo/espaço/discurso, não exatamente pelas suas possíveis respostas, mas principalmente pelas possibilidades reflexivas que apresentam. Dessa forma entendemos como fundamento das tensões relacionais decorrentes do estabelecimento Kaingang no Morro do Osso, uma preocupação geopolítica civilizatória, forma através da qual se concretizam no espaço os elementos factuais decorrentes da perspectiva neocolonial. Mais que uma 'democrática sensibilização' com a "degradação" enxergada por determinados atores sociais na qual supostamente se encontram os "índios", a refutação de sua presença no morro é reforçada pelo reconhecimento deste grupo kaingang enquanto elemento que se contrapõe a uma concepção de uma "natureza" anacrônica, de um espaço "limpo", livre de ação antrópica ${ }^{29}$, que é

\footnotetext{
${ }^{27}$ Este fato pode ser mais concretamente observado na relação da direção do parque com a possibilidade de haver ou não um cemitério indígena em sua extensão. Se num primeiro momento, antes da entrada dos Kaingang o fato havia sido pensado enquanto um chamariz turístico dando visibilidade a existência do parque, após a entrada dos indígenas este foi reconsiderado, e até mesmo refutado a luz das evidências fazendo com que a diretoria desviasse do assunto até que se assumiram "provas" de que o cemitério indígena, se eventualmente ainda existisse, seria proto-Guarani (Araxane) e não Kaingang. Indigenicidade do cemitério, portanto deveria remeter a um índio que não mais existia a não ser num passado remoto, para além de qualquer demanda ou reivindicação, nesse sentido desconectado dos indígenas contemporâneos.

${ }^{28}$ Não estamos tratando aqui do passado em termos históricos, e sim enquanto signos, mitos que agregam significado dentro de uma determinada cosmovisão.

${ }^{29}$ Basta mencionarmos a concepção de "natureza intocada" que fundamenta grande parte dos atuais trabalhos nas áreas acadêmicas biológica e ecológica, onde considera-se como hipótese inicial das metodologias de pesquisas e conjecturações sobre a vida, sua dispersão e ocupação espacial nos termos de uma dinâmica onde observa-se fauna e flora como participante de fenômenos "naturais" e as experiências do ser humano no planeta são vistas em termos de interferências, desarmoniozas e agentes de desequilíbrios sistêmicos. Notemos aqui a correlação deste modelo analítico da "ecologia planetária $e$
}

Espaço Ameríndio, Porto Alegre, v. 2, n. 2, p. 52-82, jul./dez. 2008. 
SALDANHA e SOUZA PRADELLA - A presença Kaingang no Morro do Osso ...

projetada pelos citadinos na paisagem do Morro do Osso, concepção que configura este espaço da pretendida cidade enquanto mais um "aparelho urbano" 30.

Nesse sentido, podemos ao menos parcialmente responder nossos questionamentos iniciais. O pensamento neocolonial busca fundamentar noções rígidas de "territórios de origem" ameríndios, geralmente distantes dos lugares que se busca deslegitimar sua presença, como no "alto da serra", ou na Amazônia, no Paraguai. É como se suas identidades tivessem sido elaboradas e reelaboradas em espaços confinados aos quais devem se limitar, tal qual a imagem de um estado nacional; e não num caminhar constante através do qual no mais das vezes, estes grupos concebem sua existência ${ }^{31}$. Questiona-se portanto na alteridade indígena, elementos "inquestionáveis" de sua própria identidade: como se os ancestrais europeus do que hoje chamamos "brasileiros", com suas lógicas de propriedade privada, fronteira rígida e organização estatal fossem "naturais" ou "milenares" nas terras baixas da América do Sul.

O que se propôs aqui foi um recorte sob a ótica das relações conflitantes geradas perante a problemática da questão das espacialidades étnicas na geopolítica nacional e a adequação destas para a "promoção do bem estar" destes grupos sociais no Brasil. O que tencionamos foram reminiscências sócio-discursivas e suas atualizações, sobre as questões indígenas no "Brasil". Questões estas geradas no contexto dos movimentos geopolíticos "colonialistas" a partir da "descoberta" do que se chamou "novo mundo". Ora, apenas um

\footnotetext{
humana" (já percebendo a distinção) ao modelo naturalizado da dicotomia entre "natureza" $e$ "cultura".

${ }^{30}$ É preciso aqui ressaltar as especificidades taxonômicas sustentadas pelas leis de proteção ambiental no que diz respeito as diversas "categorias" de espaços de preservação prescritos: assim, apontamos as diferenças impostas ao arbitrar que determinado local venha a ser um parque natural, por exemplo, ou uma reserva ecológica. Notamos no primeiro, a menção a utilização apreciativa-estética e, no segundo, uma questão de preservação técnica-paliativa.

${ }^{31}$ Tais discursos têm se tornado recorrentes na imprensa nos últimos anos, entre os mais ilustres estão a publicação de matéria "Made In Paraguai" escrita pelo jornalista José Edward Lima e publicada na edição 1999, de 14 de março de 2007, pág. 56, 57 e 58, da revista VEJA, onde o autor, mesmo sem sequer conhecer a grafia do etnômio, afirma energicamente que os membros da etnia "Embiá" (Mbyá) Guarani vieram todos recentemente do Paraguai em busca de benefícios do governo; e a publicação do artigo " $A$ urgência do Ministério da Amazônia" no periódico TRIBUNA DA IMPRENSA de 20 de Maio de 2008, onde seu autor, um tal Sebastião Nery, afirma que a etnia Yanomami nunca existiu, sendo uma invenção das ONG's estrangeiras que supostamente estariam manipulando indígenas como forma de dominar partes da Amazônia. Sem qualquer conhecimento sobre o assunto Nery toma como base da afirmação absurda o famoso mapa etnológico de Kurt Nimuendajú concluído no ano de 1944!
}

Espaço Ameríndio, Porto Alegre, v. 2, n. 2, p. 52-82, jul./dez. 2008. 
rompimento com a denominada "antropologia de varanda ${ }^{32 "}$ poderá nos levar ao cerne das questões relativas a um estudo menos estatizante das espacialidades indígenas.

Tratar os índios como sujeitos é estar aberto às suas reivindicações, que sempre rivalizam com os interesses privados estabelecidos em detrimento aos seus direitos originários. É aceitar sua versão da história [assim como sua territorialidade] e se retratar frente as suas acusações (SOUZA, 2004, p. 187).

Por fim, deixamos aqui para a reflexão final sobre as idéias contidas neste esforço antropológico as noções de Oliveira Filho (1998) a respeito das correlações de forças históricas que permeiam toda e qualquer percepção da atual conjuntura dos grupos indígenas no Brasil:

O destino dos povos e culturas indígenas, tal como o de qualquer outro grupo étnico ou nação, não está escrito previamente em lugar algum. A sua feição primitiva, a sua vulnerabilidade e a presumida tendência à extinção não foram jamais componentes naturais de sua existência, mas sim o resultado da compulsão das elites coloniais em instituir a homogeneidade, tentando abolir com ferro e fogo as diferenças culturais, religiosas e políticas (OLIVEIRA FILHO, 1998).

\section{Referências bibliográficas}

BAUDRILLARD, Jean. O sistema dos objetos. São Paulo: Perspectiva, 1993.

CALDRE e FIÃO, José A. Ibicui retã. Boletim Municipal, Porto Alegre, v. 6, n. 15, p. 418-424. 1943.

CRÉPEAU, Robert. A Prática do Xamanismo entre os Kaingang do Brasil Meridional: Uma breve comparação com o Xamanismo Bororo. Horizontes Antropológicos, Porto Alegre, v. 8, n. 18, 2002.

FAGUNDES, Luiz Fernando; SOUZA PRADELLA, Luiz Gustavo. Os Kujã vão na frente: uma narrativa Kaingang pela Terra. Porto Alegre: NIT-UFRGS. 2006. Vídeo.

\footnotetext{
${ }^{32}$ Cf. Stocking (1983).
} 
SALDANHA e SOUZA PRADELLA - A presença Kaingang no Morro do Osso ...

FOUCAULT, Michel. Microfísica do Poder. Rio de Janeiro: Graal, 1998.

FREITAS, Ana Elisa de Castro. Mrür Jykre: A Cultura do Cipó - Territorialidades Kaingang na Bacia do Lago Guaíba, Porto Alegre, Rio Grande do Sul, Brasil. In: KUBO, Rumi Regina et al. Atualidades em Etnobiologia e Etnoecologia. Recife: NUPEEA/SBEEE, 2006. p. 225-244. v. 3.

LIMA, José Edward. Made in Paraguai: a Funai tenta demarcar área de Santa Catarina para índios paraguaios, enquanto os do Brasil morrem de fome. Revista Veja, São Paulo, n. 1999, p. 56 - 58, 14 mar. 2007.

MERLEAU-PONTY, Maurice. Fenomenologia da Percepção. São Paulo: Martins Fontes, 1994.

MIRAPAlHEte, Simone Rodrigues (Org.). Flora e Fauna do Parque Natural Morro do Osso. Porto Alegre: SMAM, 2001.

NIMUENDAJU, Curt. Mapa Etno Histórico de Curt Nimuendaju. Rio de Janeiro: IBGE, 1987.

OLIVEIRA FILHO, João Pacheco de. Indigenismo e territorialização: poderes, rotinas e saberes coloniais no Brasil Contemporâneo. Rio de Janeiro: Editora Contracapa. 1998.

Ensaios de Antropologia Histórica. Rio de Janeiro: Editora da UFRJ, 1999.

RAUBER, Rita Cristina. O conflito de ocupação territorial do Morro do Osso em Porto Alegre, RS, Brasil, entre um grupo Kaingang e a Prefeitura Municipal de Porto Alegre. In. Reunião de Antropologia do Mercosul (RAM), 8, 2005. Montevideo.

RITA RAMOS, Alcida. Os direitos do índio no Brasil: na encruzilhada da cidadania. Série Antropologia, Brasília, n.116, p. 1-23, 1991.

ROSA, Rogério. O sistema Kujã e o sistema Caboclo do xamanismo Kaingang. In. Reunião de Antropologia do Mercosul (RAM), 8, 2005. Montevideo.

SILVA, Sergio Baptista da. Etnoarqueologia dos grafismos Kaingang: um modelo para a compreensão das sociedades Proto-Jê meridionais. 2001. 367 f. Tese (Doutorado em Antropologia Social) - PPGAS, USP. [2001].

SOUZA. José Otávio Catafesto de. Mobilização indígena, direitos originários e cidadania tutelada no sul do país depois 1988. In: FONSECA, Claudia; TERTO JR, Veriano; ALVES, Caleb Farias (Orgs.). Antropologia, Diversidade e Direitos Humanos: Diálogos Interdisciplinares. Porto Alegre: Editora da UFRGS, 2004. p. 185197.

SOUZA PRADELLA, Luiz Gustavo. Marcos de ambiência Kaingang no Morro do Osso. In: Reunião Brasileira de Antropologia (RBA), 26, 2008. Porto Seguro. 
STOCKING JR., George W. The Ethnographer's Magic: Fieldwork in British Anthropology from Tylor to Malinowski. In: . (Org.). Observers Observed: Essays on Ethnographic Fieldwork. Madison: The University of Wisconsin Press, 1983. p. $70-120$.

TOMMASINO, Kimiye. A ecologia dos kaingang na Bacia do Rio Tibagi. In: MEDRI. Moacyr E. et al. A bacia do rio Tibagi. Londrina: M E Medri. 2002. p. 81-103. 
SALDANHA e SOUZA PRADELLA - A presença Kaingang no Morro do Osso ...

\section{Anexo 1}

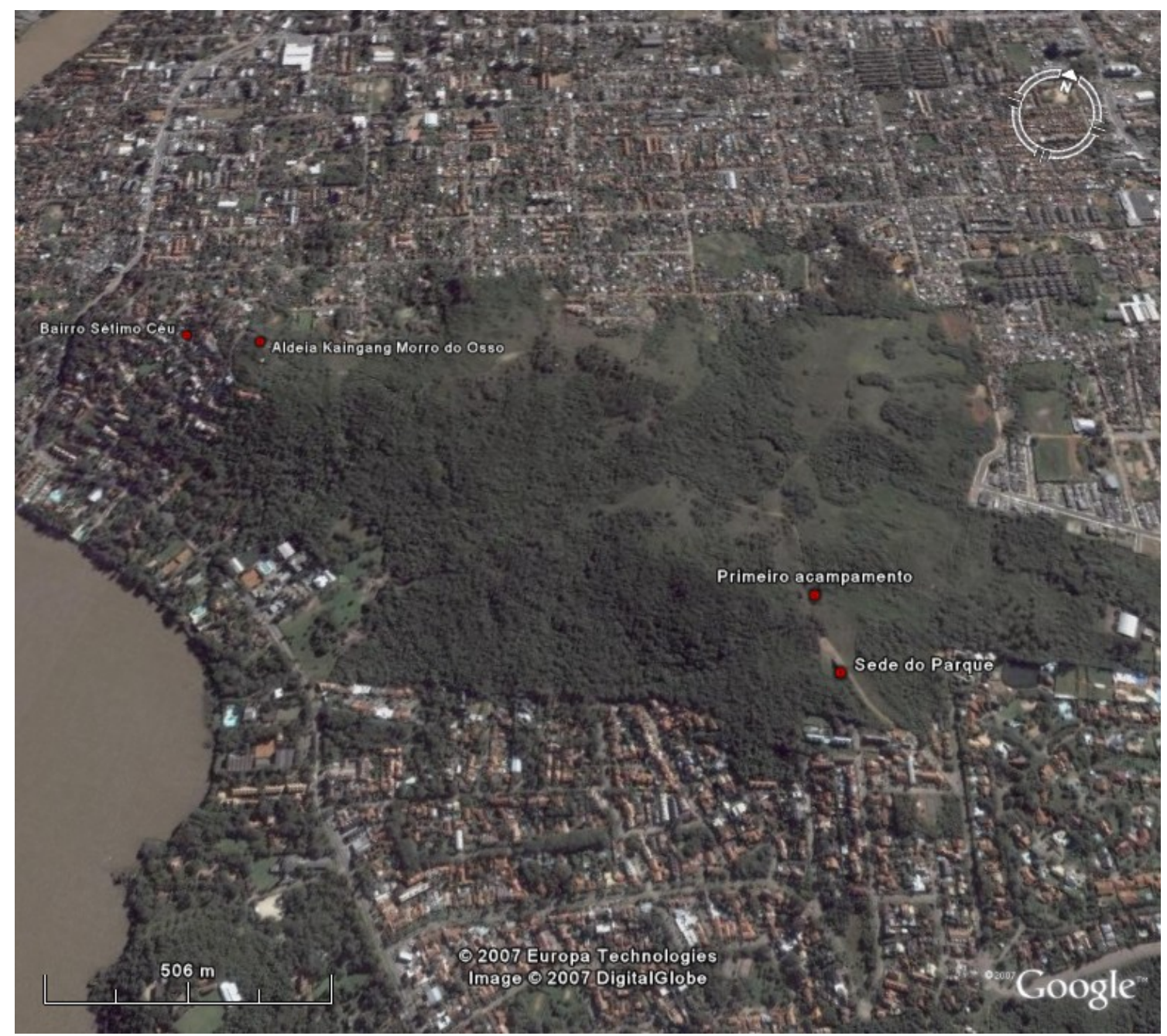

Foto A - Vista geral do Morro do Osso e suas imediações

Espaço Ameríndio, Porto Alegre, v. 2, n. 2, p. 52-82, jul./dez. 2008. 
SALDANHA e SOUZA PRADELLA - A presença Kaingang no Morro do Osso ...

\section{Anexo 2}

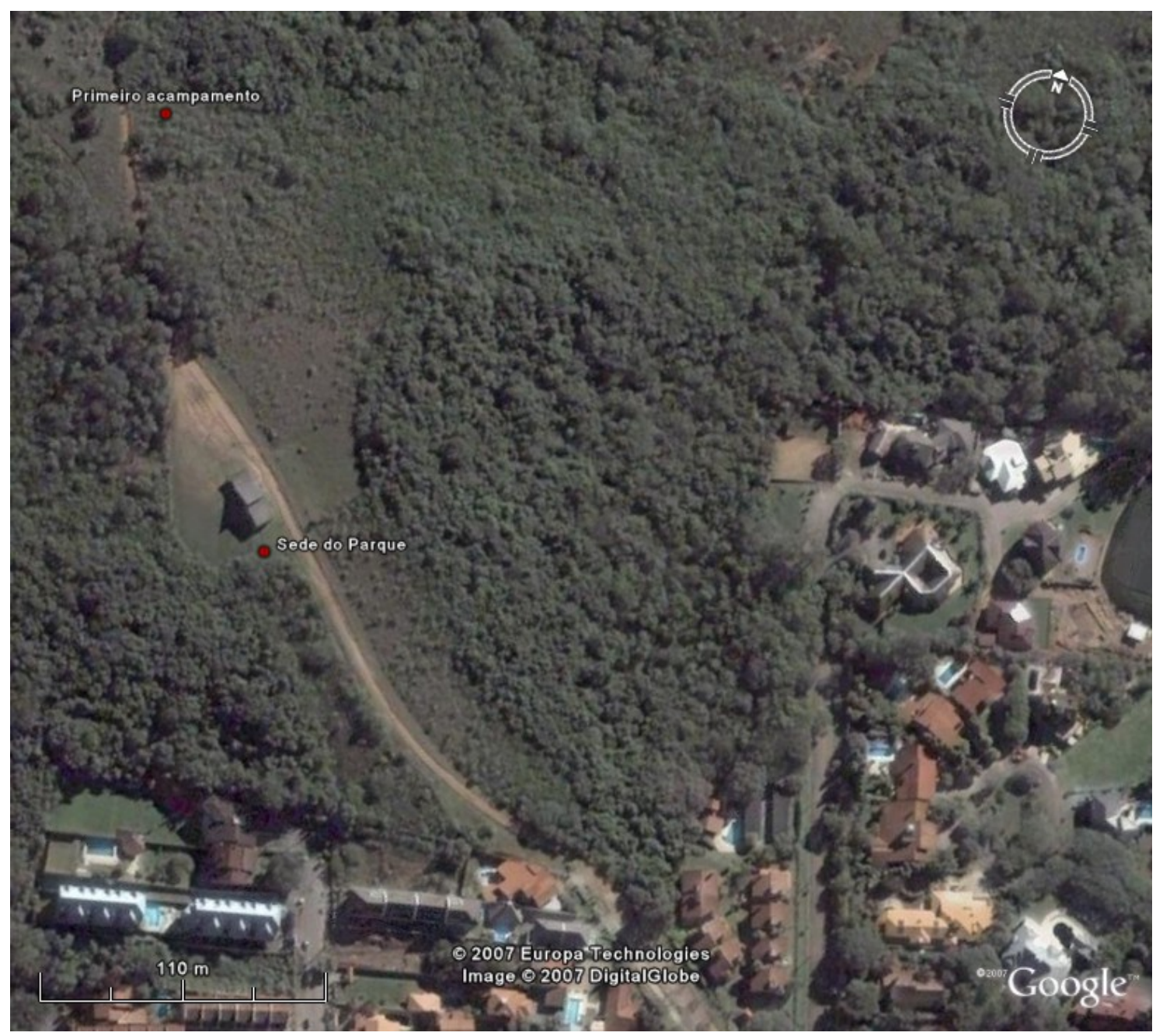

Foto B - Sede do Parque Morro do Osso e local do primeiro wäre

Espaço Ameríndio, Porto Alegre, v. 2, n. 2, p. 52-82, jul./dez. 2008. 
SALDANHA e SOUZA PRADELLA - A presença Kaingang no Morro do Osso ...

Anexo 3

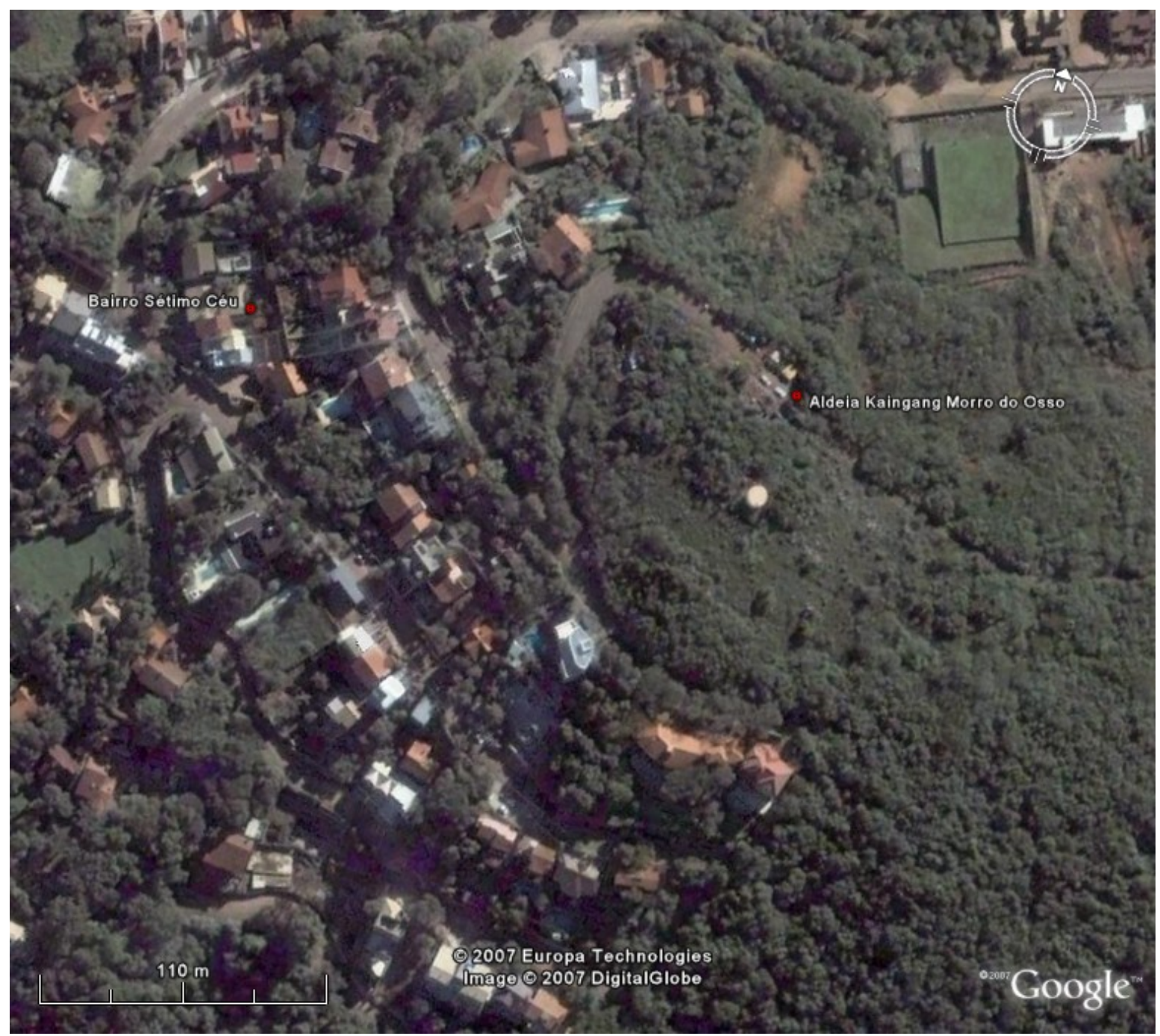

Foto C - Bairro Sétimo Céu e Emã Kaingang do Morro do Osso

Espaço Ameríndio, Porto Alegre, v. 2, n. 2, p. 52-82, jul./dez. 2008. 


\section{Anexo 4}

\section{Nota Kaingang para a Opinião Pública}

\section{Em defesa das famílias Kaingang e do meio ambiente, especialmente do futuro de nossas crianças!}

Com o pretexto de "proteger o meio ambiente" querem nos tirar daqui à força. Foi isso que o Secretário Municipal do Meio Ambiente Beto Moesch veio fazer aqui na nossa comunidade, após ter comunicado sua intenção à Brigada Militar, que se negou a agir porque não tinha uma ordem judicial, conforme publicado pela imprensa no dia de hoje, 06 de junho.

É uma vergonha o que se pensa e se faz contra nós indígenas, depois de tantos massacres, violências e mortes por mais de 500 anos. Pensávamos que o século 21 seria diferente conosco. Seria mais generoso, humano e fraterno. Que teríamos um espaço para viver. Que teríamos o aconchego, a proteção e o reconhecimento de que a natureza é nossa mãe, que acolhe e alimenta a todos, e não deve ser vista apenas como objeto de exploração, ou uma riqueza a ser reservada para a exploração futura, em nome de uma suposta proteção ambiental. "É hoje que vou tirar essa bugrada daqui"!

Foi com essas palavras que o Secretário Municipal do Meio Ambiente nos tratou ao chegar aqui no sábado, dia 04 de junho. Para quem não sabe, por muito tempo, nos chamaram de bugre para dizer que somos bicho do mato, que somos animais, que dá para matar, eliminar. Mas nós não aceitamos isso. Exigimos respeito, e queremos que justiça seja feita contra toda discriminação e preconceito. E temos certeza que a população de Porto Alegre não pensa assim e tem esse respeito por nós. Para se livrar da besteira que cometeu o Secretário Moesch, agora, se faz de coitadinho, de vítima. A verdade é que ele apanhou das mulheres indígenas Kaingang da nossa aldeia, que foram defender o jovem Volmir 
SALDANHA e SOUZA PRADELLA - A presença Kaingang no Morro do Osso ...

e a mulher que ele agrediu, quando disse "bugre não". É lamentável termos um Secretário Municipal do Meio Ambiente que desrespeita as pessoas e as culturas. Ele não foi educado para responder pelo cargo que ele representa.

Como tudo aconteceu:

No sábado, 04 de junho, por volta das 16 horas o Secretário Municipal do Meio Ambiente de Porto Alegre Beto Moesch, compareceu no Morro do Osso, parecendo que estava embriagado e transtornado. Ele invadiu a comunidade indígena Kaingang do Morro do Osso e aos gritos dizia que agora ia mostrar como arrancar os barracos da bugrada do Morro do Osso.

Logo que o Secretário Moesch chegou na comunidade indígena o jovem Kaingang Volmir foi procurar saber o que se estava acontecendo, uma vez que no local estavam ele, algumas crianças e mulheres que trabalhavam na confecção do artesanato. O Vice-Cacique não se encontrava no local porque conversava mais adiante, dentro do Parque, com algumas pessoas que diziam ser da Prefeitura de Porto Alegre e que haviam chegado momentos antes. Quando Volmir se aproximou do Secretario Moesch, que ele nem sabia de quem se tratava, este Ihe falou "que arrancaria, nem que fosse na marra, os barracos dos índios". Volmir disse que não estava entendendo, então o Secretário retrucou: "E vou começar por aqui"! Imediatamente agarrou uma cadeira que estava próxima e a arremessou contra Volmir, que conseguiu se livrar. Em seguida o Secretário empurrou com violência, jogando ao chão, uma indígena grávida de sete meses. Foi quando as seis mulheres da comunidade, que trabalhavam com artesanato, saíram em socorro daqueles que estavam sendo agredidos pelo Secretário Beto Moesch. Ele gritava "vou arrancar esta bugrada daqui". As mulheres partiram para cima do agressor e deram-Ihe arranhões e tapas na cara. Até aquele momento não sabiam que se tratava de um Secretario Municipal.

Estes são os fatos verdadeiros e não aquilo que o Secretário anda dizendo nos jornais. Lamentavelmente uma autoridade municipal age em nome de uma prefeitura, em nome de um cargo público de maneira arbitrária, violenta, completamente desnorteada e com a aparência de estar embriagado. E para agravar a situação em um sábado à tarde, fora de expediente, sem autorização, sem ordem judicial, contra pessoas 
SALDANHA e SOUZA PRADELLA - A presença Kaingang no Morro do Osso ...

que apenas aguardam que os órgãos públicos federais cumpram com sua responsabilidade de criar o Grupo de Trabalho para identificação e delimitação da Terra Indígena Morro do Osso.

Nós, da comunidade indígena, estamos indignados porque além de tudo o que relatamos, o Secretário Moesch nos ofendeu com expressões preconceituosas nos chamando de bugrada e disse nos jornais que somos um bando de bandidos. Nós exigimos respeito e queremos que nossos direitos sejam resguardados conforme estabelece a Constituição Federal em seu Artigo 231, bem como o que estabelece a Convenção 169 da OIT - Organização Internacional do Trabalho quando trata dos Povos Indígenas.

O Secretário de Meio Ambiente do Município de Porto Alegre Beto Moesch, através desta atitude irresponsável, insana, ilegal, arbitrária compromete o diálogo pela busca de solução para os problemas sociais e compromete, acima de tudo, a credibilidade das autoridades públicas, principalmente de Porto Alegre.

Nós, através desta nota pública, denunciamos o Secretário Beto Moesch por agressão, invasão da comunidade e por preconceito contra os Povos Indígenas. Por isso, exigimos: - que seja aberta uma sindicância administrativa na Prefeitura de Porto Alegre para apurar as responsabilidades e punir os responsáveis pela ação arbitrária do Secretário de Meio Ambiente contra a comunidade indígena do Morro do Osso; - que seja aberto inquérito policial e que o Secretário seja processado por invasão da comunidade indígena, por agressão física e por crime de racismo; - que o Ministério Público Federal acione judicialmente o Secretário por calúnia e difamação, em função de seus pronunciamentos em jornais e na televisão, onde afirma que os índios acampados no Morro do Osso são bandidos e traficantes; - que a Funai crie imediatamente o grupo técnico para proceder aos estudos de identificação e delimitação da terra indígena Morro do Osso.

Porto Alegre 06 de junho de 2005. Comunidade Indígena Kaingang do Morro do Osso. 